THE ENFORCEMENT OF SOCIO-ECONOMIC RIGHTS

ISSN 1727-3781

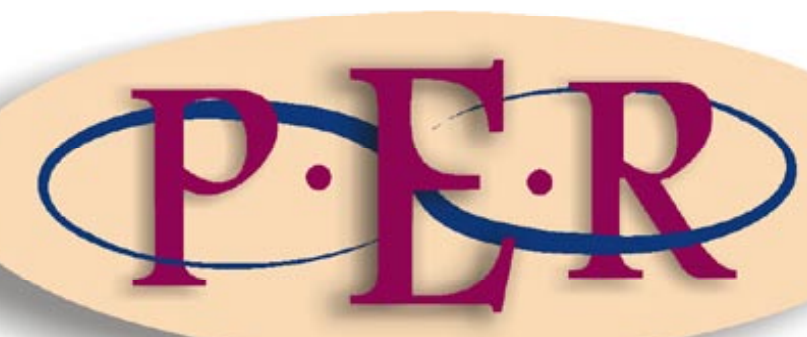

2007 VOLUME 3 


\title{
THE ENFORCEMENT OF SOCIO-ECONOMIC RIGHTS
}

\author{
RJ de Beer ${ }^{*}$ \\ S Vettori ${ }^{* *}$
}

\section{Introduction}

The shameful fact that the majority of South Africa's population lives in abject poverty is well documented. ${ }^{1}$ Poverty on such a large scale has been described at worst as the main cause and at best as a major contributing factor to a multitude of serious social problems such as the high rate of violent crime, the high rate of illiteracy, the high incidence of HIVIAids and unemployment. Bluntly put, poverty is to blame for jeopardising the very fabric of South African society and consequently the security of the South African population. It is no small wonder that the main objective of the Constitution of the Republic of South Africa, 1996 (the Constitution) has been described as the alleviation of poverty. $^{2}$

The legislature has made a very bold attempt to uplift its citizens. Amongst others, the Social Assistance Act 59 of 1992 (Social Assistance Act) ${ }^{3}$ provides for monthly payments to citizens under certain prescribed conditions. In situations where other legislation does not provide a remedy for those unable to

* Advocate of the High Court of South Africa and a member of the Society of Advocates Johannesburg, B Juris LLB (PU for CHE) LLM (UP).

** Associate Professor, Faculty of Law, University of Pretoria, BA LLB (Wits) LLM (UNISA) LLD (UP).

1 See Hirscowitz "Statistics South Africa 2000".

2 Per Chaskalson P in Soobramoney v Minister of Health, Kwazulu-Natal 1998 (1) SA 765 (CC) at 770-771 at par 8. He stated: "We live in a society in which there are great disparities in wealth. Millions of people are living in deplorable conditions and in great poverty. There is a high level of unemployment, inadequate social security, and many do not have access to clean water or to adequate health services. These conditions already existed when the Constitution was adopted and a commitment to address them, and to transform our society into one in which there will be human dignity, freedom and equality, lies at the heart of our new constitutional order. For as long as these conditions continue to exist that aspiration will have a hollow ring."

3 As amended by the Welfare Laws Amendment Act 106 of 1997. 
care for themselves the Constitution provides for justiciable ${ }^{4}$ socio-economic rights. ${ }^{5}$ Unfortunately legislative rights alone have proved insufficient and all too frequently the constitutional values and aspirations of human dignity and equality have had a "hollow ring". 6 The most obvious reason for this failure of delivery on the part of the government is of course a shortage of financial resources. ${ }^{7}$ However, this is not the only reason for this failure. Another reason has been a simple disregard for the terms of legislation and court orders by organs of the state and state employees. ${ }^{8}$ We are of the view that in order to avoid such a dire result, in the interests of all South Africans, the courts, given their broadly framed constitutional powers, should be adventurous in crafting means to ensure that their orders are properly implemented and adhered to. The purpose of this article is to explore the role that courts can play in ensuring proper implementation of both the terms of social security legislation as well as the implementation of court orders. ${ }^{9}$ Although it may appear that our proposals are limited to specific problems relating to non-compliance with Eastern Cape welfare judgments, there is no reason for limiting our proposals to this province's judgments. We propose that the solution suggested herein should be utilised where there is flagrant disregard of court orders by state officials.

4 Government of the Republic of South Africa v Grootboom 2000 (11) BCLR 1169 (CC); Minister of Health v TAC 2002 (5) SA 721 (CC).

5 S 26 and 27 of the Constitution: "The Constitution guarantees a set of justiciable socioeconomic rights which impose negative and positive duties on the State".

6 Per Chaskalson P in Soobramoney v Minister of Health, Kwazulu-Natal 1998 (1) SA 765 (CC) 771 at par 8.

7 See Soobramoney v Minister of Health, Kwazulu-Natal 1998 (1) SA 765 (CC); Government of the Republic of South Africa $v$ Grootboom 2000 (11) BCLR 1169 (CC); Minister of Health v TAC 2002 (5) SA 721 (CC).

8 Another reason is that state officials are not aware of their obligations and competencies in giving effect to court orders sounding in money. See Thozamile Eric Magidimisi $v$ The Premier of the Eastern Cape Case Number 2180/04 at par 6.

9 Although most of the cases discussed occurred in the Eastern Cape, it is obvious that what we propose applies to the whole country. In fact this problem, although concentrated in the Eastern Cape, is also prevalent in Natal. See Broughton The Mercury http://www.iol.co.za/ $29 \mathrm{Dec}$ at 3. The concentration of the Eastern Cape is a natural consequence of the fact that this is where much of the flagrant disregard of court orders has occurred. 


\section{Failure to implement legislative provisions of the Social Assistance Act and failure to adhere to court orders}

The state's failure to implement legislative provisions of the Social Assistance Act is rife in the Eastern Cape. ${ }^{10}$ Such failure comes in various forms: a failure to timeously and expeditiously consider applications for social grants and a failure to implement payments once the social grants have been approved. ${ }^{11}$ The cause of this state of affairs has been attributed to sheer laziness and incompetence on the part of the officials of the Department of Social Development. ${ }^{12}$ This maladministration in the Eastern Cape has been described as a "conspicuous and endemic". ${ }^{13}$ Given the fact that the victims of this maladministration are poor and lack the necessary financial and other means to turn to the courts for help, this means that the plethora of cases that reach the courts is only the tip of the iceberg. ${ }^{14}$

Clearly such a state of affairs threatens the very foundations of our Constitution and democracy thus justifying intervention by the judiciary. Plasket $\mathrm{J}$ comments as follows in this regard:

10 Nugent JA in MEC $v$ Kate 2006 (4) SA 478 (SCA) 483 at par 5 notes: "What is particularly distressing is that there seems to be no end in sight. An affidavit deposed to by the attorney for the Black Sash (which was admitted as amicus curiae in the present appeal) records that, in a period of six weeks during the latter part of 2005, there were almost 2000 such cases on the role of the High Court. On one occasion Plasket J noted that there were 102 cases relating to social assistance on his Motion Court roll for that week, and he went on to say the following: "If this volume of social assistance cases had been unique to one week's Motion Court roll, it would have been cause for concern. Unfortunately it is a phenomenon that is common: the Judges of this Division have grown accustomed to the depressing tales of misery and privation contained in an ever-increasing volume of cases that clog their Motion Court rolls in which applicants complain about administration torpor in the processing of their applications for social assistance. To make matters worse, this situation is not new. Over the last four or five years Judges have commented, often in strident terms, about the unsatisfactory performance of the respondent's department in the administration of the social assistance system in the province'."

11 See the comments of Nugent JA in MEC v Kate 2006 (4) SA 478 (SCA) 483 at par 4-6.

12 See the comments of Plasket J in Vumazonke v MEC 2005 (6) SA 229 (SE) 233 at par 3, 234 at par 4-5 and 235 at par 6-8 where he quotes a number of judges who have had to deal with such cases.

13 Per Nugent JA in MEC $v$ Kate 2006 (4) SA 478 (SCA) 483 at par 3.

14 Plasket J in Vumazonke v MEC 2005 (6) SA 229 (SE) 237 at par 10 comments: 'What escalates what I have termed a problem into a crisis is that the cases that are brought to court represent only a tip of the iceberg." 
Judges have criticised the performance of the Department of Social Development, not because they see themselves as superombudsmen or wish to involve themselves in politics, but because the administrative failings of the department have consequences that bring its performance within the heartland of the judicial function: those failings infringe or threaten the fundamental rights of large numbers of people to have access to social assistance, to just administrative action and to human dignity. Note that in Mashavha v President of the Republic of South Africa and Others (2005) (2) SA 476 (CC) 2004 (12) BCLR 1243 at par [51], Van der Westhuizen J commented that social assistance was 'an area of governmental responsibility very closely related to human dignity'. When rights are infringed or threatened, the impugned conduct becomes very much the business of the judiciary; s 38, s 165, s 172 of the Constitution of the Republic of South Africa, 1996 (the Constitution), make that abundantly clear, placing as they do a duty on the judiciary to remedy such infractions. The problem faced by the judiciary in the Eastern Cape in social assistance cases is, however, of a different order. It relates to the boundaries of the judicial function- to the limits of the institutional competence of the courts to engineer administrative efficiency. ${ }^{15}$

Given its duties and mandate in terms of the Constitution, and the urgency of the matter, some members of the judiciary have been rather bold and creative in crafting court orders that enable the implementation of the provisions of the Social Assistance Act so as to uphold rights embodied in the Constitution. What follows is a discussion of the various options the courts have implemented in their quest to uphold the principles of the Constitution especially human dignity. The judiciary will have to engineer remedies not only for breaches of legislative provisions, but also for a failure to implement court orders. The failure of the Department of Social Welfare in the Eastern Cape to comply with court orders to pay pensions or grants has been described as 'distressing'. ${ }^{16}$ Froneman J has identified various reasons for non-compliance of court orders by the Department of Social Welfare in the Eastern Cape:

The province's response to the individual cases falls into three broad categories. In one category it objected to payment on the grounds that the judgments were wrongly granted and should be rescinded. A second category related to those instances where the judicial process and the administrative process of assessing the applications 
ran simultaneously'. In most of these instances the department's calculations differed from the court order and it appears that the province preferred to follow its own assessment rather than comply with the exact terms of the court order. The third category related to those instances where the court order was in fact complied with. ${ }^{17}$ (Footnotes omitted.)

The reasons for non-compliance are a clear indication of the ignorance and perhaps even arrogance of state officials with regard to their duties in acting on behalf of the state, the force and relevance of the Constitution and the jurisdiction of the courts. ${ }^{18}$

A disregard for court orders by the state however, is not limited to a refusal to pay social grants to certain individuals in terms of the Social Assistance Act. The now well known cases of Government of the Republic of South Africa $v$ Grootboom, $^{19}$ Minister of Health $v$ Treatment Action Campaign ${ }^{20}$ (TAC) and more recently EN and Others $v$ The Government of the Republic of South Africa and Others ${ }^{21}$ (EN case) demonstrate a disregard for court orders on an even larger scale. In these cases the state was found to have breached its constitutional obligations to provide certain socio-economic rights in terms of the Constitution to certain groups of people. Despite a declaratory order in Grootboom to the effect that the state had breached its duty to provide housing in terms of section 26 of the Constitution very little, if anything has since been done by the state to remedy the situation. ${ }^{22}$ In TAC, despite a mandatory order to the effect that the state should take certain steps, the intervention of the TAC after the order was granted "was probably the only way in which it could

17 Thozamile Eric Magidimisi v The Premier of the Eastern Cape Case Number 2180/04 at par 15.

18 There could at times be other reasons such as lack of training and capacity etc. However, this goes beyond the scope of this article as we are only concerned with the intentional and flagrant disregard of legislative provisions and court orders.

19 Government of the Republic of South Africa v Grootboom 2001 (1) SA 46 (CC).

20 Minister of Health $v$ TAC 2002 (5) SA 721 (CC).

21 EN $v$ The Government of the Republic of South Africa Unreported Case No 4576/06 DCLD.

22 See Swart 2005 SAJHR 215 at 223-224; Davies 200622 SAJHR at 314; Pillay 2002 Economic and Social Rights Review 11, 12. Note that the state did adopt ch 12 of the National Housing Code on Emergency Housing Assistance. There have been difficulties at local government level in implementing the programme see City of Johannesburg $v$ Rand Properties 2006 (6) Case No 253/06 (SCA). 
achieve some successes". ${ }^{23}$ In the EN case the state had ignored an order granted by Pillay $\mathrm{J}$ in terms of which the state was obliged inter alia to provide anti-retroviral treatment to prisoners.

The consequence of a judiciary that is impotent to enforce its judgments against the state does not do justice to its role in our new-found democracy and the constitutional values upon which it is built. We are of the view that in order to avoid such a dire, almost unthinkable result, in the interests of all South Africans, the courts should be adventurous in crafting means to ensure that their orders are properly implemented and adhered to. Recently reported judgments more clearly demonstrate a will on the part of the judiciary to fashion innovative remedies in order to prevent this. ${ }^{24}$ What follows is an examination of what the courts have done and what they possibly can do, not only to ensure compliance with the terms of their orders but also what steps can be taken when faced with non-compliance of orders.

\section{What powers do the courts have to create novel remedies?}

The courts have wide discretionary powers to fashion remedies in order to ensure that their orders are complied with. The Supreme Court of Appeal in President of the Republic of South Africa and Others $v$ Modderklip Boerdery (Pty) Ltd (Agri SA and Legal Resources Centre, Amici Curiae) ${ }^{25}$ citing Fose $v$ Minister of Safety and Security ${ }^{26}$ and Minister of Health and Others $v$ Treatment Action Campaign and Others ${ }^{27}$ stated that the -

...courts have a duty to mould an order that will provide effective relief to those affected by a constitutional breach.

23 Swart supra n 22 at 224.

24 Minister of Health v TAC 2002 (5) SA 721 (CC); Thozamile Eric Magidimisi v The Premier of the Eastern Cape Case Number 2180/04 and MEC v Kate 2006 (4) SA 478 (SCA).

25 President of the Republic of South Africa v Modderklip Boerdery 2004 (6) SA 40 (SCA) 61 at par 42.

26 Fose $v$ Minister of Safety and Security 1997(3) SA 786 (CC) 834 at par 94.

27 Minister of Health v TAC 2002 (5) SA 721 (CC) 756 at par 102. 
This duty or power is granted by the Constitution: Section 38 of the Constitution provides that a court may grant 'appropriate relief' in circumstances where an infringement of any right contained in the Bill of Rights has been established. In terms of sections 172(1)(b) and 167(7), when courts are faced with "any issue involving the interpretation, protection or enforcement of the Constitution" they are empowered to make any order that is 'just and equitable'. In terms of sections 173 and 8(3) the courts are empowered to develop the common law in order to give effect to constitutional rights. Clearly the Constitution grants the courts extensive scope in fashioning their orders. ${ }^{28}$ Our discussion is limited to the means adopted in the court order to ensure that the order is complied with. $^{29}$

In spite of such broadly framed powers in terms of the Constitution there have been instances where the judiciary may have displayed unnecessary caution with regard to crafting orders to ensure compliance. This is especially the case when the state is required to take action in terms of an order. Such caution is motivated by a fear of encroaching on executive territory. The result has been conservative and ineffective court orders. In Minister of Health $v$ TAC $^{30}$ the Constitutional Court held that although an order to the effect that state has failed to give effect to its constitutional obligations in formulating and implementing policies may constitute an intrusion into executive functions, ${ }^{31}$ the

28 The latitude given to the courts to fashion remedies is not limited to their scope to fashion means to ensure compliance with the orders. It extends to the power to decide what exactly the offending party has to do in order to remedy the situation. With regard to ensuring governmental compliance with its duty to provide for certain socio-economic rights the courts have generally adopted a conservative approach for fear of treading on executive territory. Consequently court orders dealing with this issue have thus far been somewhat vague in the sense that the orders do not explicitly provide for what it is that the government should do in order to comply with its constitutional duties. See Davies supra $n$ 22.

29 Remedial options need not necessarily be pursued in the alternative. The facts of a case may require a combination of the different orders.

30 Minister of Health $v$ TAC 2002 (5) SA 721 (CC).

31 Davies supra n 22 at 304 explains the reasons for the reluctance of the Constitutional Court to formulate policy: "In general the Constitutional Court has been reluctant to impose additional policy burdens on government, notwithstanding the imperative to give some content to these rights as contained in the text of the Constitution. The less the burden of the Constitutional Court to exercise supervision over the executive, the more comfortable it feels in its role as the ultimate enforcer of accountability. Thus, the Court provides an interpretation of these rights and then approaches the question of appropriate relief in a manner that proclaims its constitutional custodial role without forcing the hand of the 
courts are mandated and obliged to make such an order in terms of the Constitution. Despite this acknowledgement, the court limited itself to a declaratory order and failed to make use of a structural interdict. The court said:

The order made by the High Court included a structural interdict requiring the appellants to revise their policy and to submit the revised policy to the Court to enable it to satisfy itself that the policy was consistent with the Constitution. In Pretoria City Council this Court recognised that Courts have such powers. In appropriate cases they should exercise such power if it is necessary to secure compliance with a court order. That may be because of a failure to heed declaratory orders or other relief granted by a Court in a particular case. We do not consider, however, that orders should be made in those terms unless this is necessary. The government has always respected and executed orders of this Court. There is no reason to believe that it will not do so in the present case. ${ }^{32}$

In the wake of Grootboom ${ }^{33}$ such confidence in the government's will to comply with court orders was misplaced and naïve. The failure of government to act until further prodding by the $\mathrm{TAC}^{34}$ is further testimony to the fact that the Constitutional Court erred in assuming that it was unnecessary for it to play a supervisory role in order to ensure implementation of its order by the government. In a similar vein, the Constitutional Court in the case of Rail Commuters Action Group and Others v Transnet Ltd t/a Metrorail and Others ${ }^{35}$ refrained from granting a structural interdict and restricted its order to a declaratory order. The court concluded that even though an order putting Metrorail and the Commuter Corporation on terms to take steps to implement that order would have been competent, since there was nothing in the papers to indicate that Metrorail and the Commuter Corporation would not take steps to implement the court order, it was not clear that such an order would be appropriate. The court therefore limited its order to a declaratory order.

executive. The source of this approach is to be found not only in the restrictive legal repertoire employed by the Court, but also in the political and the economic context in which current legal practice is located...".

32763 at par 129.

33 See Pillay supra $\mathrm{n} 22$ where research revealed that two years after the order was granted it was still far from being properly implemented.

34 See Swart supra $\mathrm{n} 22$ at 224.

35 Rail Commuters Action Group v Transnet Ltd t/a Metrorail 2005 (2) SA 359 (CC). 
Having noted the unfortunate consequences of an unwillingness and ignorance on the part of the government and its organs to abide by court orders ${ }^{36}$ combined with the cautious approach adopted by the courts thus far, especially the Constitutional Court, various possible options available to the judiciary that will ensure compliance with its orders will be discussed.

\section{$4 \quad$ The structural interdict}

Although there is no clear and formal definition of a structural interdict, ${ }^{37}$ briefly, it is a remedy in terms of which the court orders an organ of state to perform its constitutional obligations and to report to the court on its progress in doing so. ${ }^{38}$ In other words, the court plays a supervisory role in ensuring state compliance with its order. The structural interdict is particularly useful and appropriate when it comes to enforcing state compliance with its duty to provide socio-economic rights. Firstly, since the state is obliged to report to the court on its progress in implementing the terms of the order, the structural interdict is particularly suitable for the enforcement of duties which are ongoing, such as socioeconomic rights. A feature rendering the structural interdict attractive in these circumstances is that the court can devise a time frame within which the order must be complied with. ${ }^{39}$ Secondly, structural interdicts are also appropriate when the state's conduct results in a breach of fundamental rights and affects a

36 Froneman $\mathrm{J}$ aptly describes the consequences in Thozamile Eric Magidimisi $v$ The Premier of the Eastern Cape Case Number 2180/04 at par 1 as follows: "In a constitutional democracy based on the rule of law final and definitive court orders must be complied with by private citizen and the state alike. Without that fundamental commitment constitutional democracy and the rule of law cannot survive in the long run. The reality is as stark as that."

37 In Thozamile Eric Magidimisi v The Premier of the Eastern Cape Case Number 2180/04 Froneman J at par 29 stated: "Whatever the proper legal pigeon hole may be for this kind of order, it has been sanctioned in appropriate cases by the Constitutional Court." $\mathrm{Mr}$ Trengrove, for the applicant, referred to it as a "mandamus with a wrinkle".

38 See the description provided by Trengrove 1999 Economic and Social Rights Law Review at 8-10.

39 In Thozamile Eric Magidimisi v The Premier of the Eastern Cape Case Number 2180/04 at par 39 Froneman J ordered that the Department of Social Development and the Premier comply with the order within a specific time frame. 
group of people as opposed to one or two individuals. In granting a structural interdict in Kiliko v Minister of Home Affairs and Others, ${ }^{40}$ Van Reenen J stated:

....as the manner in which the Department discharges its duties and obligations to refugees not only deleteriously affects the freedom and dignity of a substantial number of disadvantaged human beings, but also fails to adhere to the values embodied in the Constitution, I incline to the view that the instant case is an appropriate one for the granting of a structural interdict.

Very briefly, this case concerned the policy and procedure adopted by the Western Cape refugee centre of inter alia accepting only 20 applications for asylum per day. The effect of this policy was that since asylum seekers whose applications were not attended to remained 'illegal foreigners', they ran the risk of detention and deportation in terms of sections 32, 33 and 34 of the Immigration Act. ${ }^{41}$ As pointed out by Van Reenen $\mathrm{J}$ this is obviously an invasion of the constitutionally protected rights to human dignity and freedom of security of one's person. Consequently, the remedy of a structural interdict was considered to be appropriate. ${ }^{42}$ Thirdly, given the extent of poverty in South Africa, the provision of these rights is usually urgent, thus rendering a structural interdict in terms of which the state has to report back on its progress within a given time frame particularly useful.

In the recently decided case of Thozamile, ${ }^{43}$ Froneman $\mathrm{J}$ inter alia made use of a structural interdict in order to ensure compliance with his order. Briefly, the applicant in this case sought to ensure that the provincial government pays its debts in terms of various money judgments ordered by the High Court. It was common cause that the province had in a number of instances failed to comply with court orders to pay certain amounts of money to various successful litigants. The applicant, Thozamile, approached the court in three different capacities: Firstly he acted as representative of his late mother's estate. The

40 Kiliko v Minister of Home Affairs 2006 (4) SA 114 (C) 127 at par 32.

41 Immigration Act 13 of 2002.

42 See the judgments in S v Mfezeko Zuba and 23 similar Cases 2004 (4) BCLR 410 (E); Ngxuza v Permanent Secretary, Department of Welfare, E Cape 2001 (2) SA 609 (E) at $633-634$.

43 Thozamile Eric Magidimisi v The Premier of the Eastern Cape Case Number 2180/04. 
court had given judgment in her favour against the province for the payment of a disability grant in the amount of $\mathrm{R} 29,400.00$ plus interests thereon and costs in December 2002. At the time of the application, only the costs had been paid, while the amount due in terms of the disability grant and the interest thereon remained unpaid. Secondly he acted in the capacity of representative of 59 other judgment creditors whom the province had failed to pay. Thirdly, the applicant acted in the public interest in that the province's failure to abide by court orders made against it on a broad scale in social grant matters is a matter that should be addressed in the interests of the public at large. The applicant sought an order -

... to compel the respondents to fulfil their constitutional and statutory obligation to comply with court orders made against the province, by not only taking all the steps necessary to ensure payment of the sums owing by the province to the applicant and others, but also to report to the court the manner and extent of their compliance. If they fail to do this the applicant seeks leave to approach this court again for further relief. ${ }^{44}$

In granting the structural interdict requested, Froneman $\mathrm{J}$ pointed out that it is a remedy that has been sanctioned by our courts. ${ }^{45} \mathrm{He}$ stated that the structural interdict was appropriate in the circumstances before him because the failure by the state to ensure compliance with court orders had been 'persistent and lengthy'. ${ }^{46}$ The implication seems to be that court supervision is necessary because the state cannot be trusted to do its duty and the non-compliance occurs on an ongoing and continuous basis. By granting the structural interdict the court was not encroaching on executive territory. It was not telling the state how to go about performing its statutory and legislative duties. It was simply ensuring that the state did what it was obliged to do and doing what it in turn was constitutionally bound to do. In the words of Froneman J:

The Constitution has been described as a "transformative" constitution in that it commits the South African people to achieve a new kind of society in which people have the social resources they

44 Par 29. Further relief would entail ia contempt proceedings.

45 Par 32. It was also sanctioned in Minister of Health v TAC 2002 (5) SA 721 (CC).

46 Par 33. 
need to exercise their rights meaningfully. In this case the constitutional duty of the respondents was to give effect to the fundamental right of the applicant and others to social security and assistance under section 27 of the Constitution, by properly administering the provisions of the Social Assistance Act. This includes reasonable measures to make the system effective. The constitutional duty of the courts in this regard is not to tell the respondents how to do this, but merely to ensure that they do take reasonable measures to make the system effective. In this manner the respondents (representing the province), as well as the courts, are enjoined to ensure the realisation of the same goal, albeit in different ways. The respondents do not have a choice but to administer the administration of grants in a reasonable manner making the system effective. The courts have no choice but to give redress when this is not done. And after the courts have made a final pronouncement on the issue in accordance with legal procedures, the respondents have no constitutional choice to disregard the courts' judgments. If they nevertheless do, the courts in turn have no constitutional choice other than to ensure as far as possible that practical effect is given to those judgments. ${ }^{47}$ (Footnotes omitted.)

We hope that should the occasion present itself in the future, the Constitutional Court will take a less cautionary approach than it has in the past and make use of the remedy of structural relief (as the High Courts have done). In this way, successful litigants have some hope that their victories in court will have some positive practical consequences. ${ }^{48}$ A failure to do so will render the concept of justiciable socio-economic rights a mockery.

\section{$5 \quad$ Contempt of court}

Normally when a judgment creditor is faced with non-compliance with a judgment debt payable in money, the judgment debtor's property can be attached and sold in order to pay the creditor. If the state or a state organ is the judgment debtor such attachment of state property is not allowed. Section 3 of the State Liability Act ${ }^{49}$ prohibits execution against the state or a provincial government because of the disruption which execution against state assets

47 Par 26.

48 Par 29.

49 State Liability Act 20 of 1957. 
might cause. As pointed out by Conradie JA in Jayiya $v$ Members of the Executive Council for Welfare, Eastern Cape, and Another ${ }^{50}-$

$\ldots$ it just did not occur to the Legislators of 1957 , or to those who amended the Act in 1993, that the state or a Province might not promptly comply with an order of court.

The disregard for court orders by the Department of Welfare in the Eastern Cape indeed is outrageous. ${ }^{51}$ Faced with this fact, some members of the judiciary boldly have attempted to be creative in fashioning remedies for victorious litigants who despite an order in their favour sounding in money, are unable to gain any concrete benefits. For example in Mjeni v Minister of Health and Welfare, Eastern Cape, ${ }^{52}$ Jafta $\mathrm{J}$ held that officers of the state who willfully caused judgment debts not to be paid could be imprisoned for contempt of court. Jafta $\mathrm{J}$ held that the common law rule (also contained in section 1 of the Abolition of Civil Imprisonment Act $)^{53}$ that a debtor cannot be imprisoned for failing to abide by the terms of a judgment for the payment of money, is only applicable when the alternative remedy of attachment and sale in execution is available to the judgment creditor. In other words, if this remedy is not applicable, as is the case where the judgment debtor is the state, imprisonment for failing to comply with a money judgment is possible. Jafta $\mathrm{J}$ held:

The common law distinction between orders ad pecuniam solvendam and those ad factum praestandum regarding contempt of court proceedings would not... make sense in cases where the State is the judgment debtor in the light of the provisions of $s 3$ of Act 20 of 1957. It would simply mean that the judgment creditor cannot enforce the judgment... whereas his counterparts would be able to do so against judgment debtors who are private persons. Effectively, it would mean that those who sue the State run the risk of obtaining hollow and unenforceable judgments. The State could just ignore such judgments with complete impunity. ${ }^{54}$

50 Jayiya v MEC 2004 (2) SA 611 (SCA) 619 at par 16.

51 In Permanent Secretary, Department of Welfare, Eastern Cape v Ngxuza 2001 (4) SA 1184 (SCA) par 15, Cameron JA referred to the conduct of the Eastern Cape Province as "contradictory, cynical, expedient and obstructionist...as though it were at war with its own citizens."

52 Mjeni v Minister of Health and Welfare, Eastern Cape 2000 (4) SA 446 (Tk).

53 Abolition of Civil Imprisonment Act 2 of 1997.

54 Supra n 52 at $453-454$. 
This judgment was approved and followed by other judgments in the Eastern Cape. ${ }^{55}$ The justification for this approach was that the courts are empowered in terms of the Constitution to develop the common law so as to further the promotion of constitutional rights.

The Supreme Court of Appeal, per Conradie JA, in Jayiya held that this approach was incorrect because:

The common law cannot evolve in conflict with statute or basic principles of the law...Moreover the common law must evolve in a principled way. One of the fundamental tenets of the common law is that of legality: it cannot evolve in such a way as to (retrospectively) create a new crime or extend the limits of an existing one. This is what the decisions in the Eastern Cape appear to have done. Contempt of court, even civil contempt of court, is a criminal offence. The way our common law has developed, it can be committed only by deliberately mala fide ignoring orders of Court ad factum praestandum: it cannot by judicial extension be made to embrace orders ad pecuniam solvendam. Not even the Legislature can make conduct retrospectively punishable. The Constitution forbids it. An accused's right to a fair trial includes, in s 35(3)(1) the right 'not to be convicted for an act or an omission that was not an offence under either national or international law at the time it was committed or omitted'. ${ }^{56}$ (Footnotes omitted.)

Conradie JA also reasoned that it made little sense that an employee could go to prison for her employer's debt when legislation prevents her imprisonment for failure to pay her own debt. ${ }^{57}$ The practical consequence of this judgment is that successful litigants with court orders sounding in money against the state in their favour, faced with a state organ that ignores the court orders can neither successfully have state officials who were responsible for implementing the order, but failed to do so, imprisoned for contempt of court, nor attach state property in execution of the debts owing to them.

One possible solution to this problem is to have section 3 of the State Liability Act declared unconstitutional. As Froneman $\mathrm{J}$ points out this section effectively

55 See eg, East London Transitional Local Council v MEC 20004 All SA 443 (Ck) at 449.

56 Jayiya $v$ MEC 2004 (2) SA 611 (SCA) 619 at par 16 and 620 at par 18.

57 Ibid at par 16. 
places the state above the law. ${ }^{58}$ The problem with this solution, ${ }^{59}$ for our purposes, is that unless and until this section is declared to be constitutionally invalid in terms of section 172 of the Constitution, the courts will have to apply it. An alternative solution suggested by Froneman $\mathrm{J}$ is do develop and adapt the common law so as to create civil as opposed to criminal liability for contempt of court by state officials. According to Froneman J, 'an adapted common-law rule of civil contempt, shorn of its criminal elements of punishment, in the form of a declaratory order that a State functionary is in contempt of a court order ${ }^{60}$ would not offend against the rule forbidding the conviction of any person for a retrospectively created offence. According to Froneman $\mathrm{J}$, the court could in such situations make an order calling upon the state official to explain why they have not complied with the court orders and how they intend complying with them. ${ }^{61}$ But what if after the court has made such a declaratory order the responsible official still does nothing? We propose that the guilty state officials be made personally liable for the payment of damages to the judgment creditors on the basis of delict. This proposition is discussed hereunder.

On the other hand, if the court order is not a money order, there is no reason preventing a state official from being liable for contempt of court. The Supreme Court of Appeal unanimously accepted this. Nugent JA (for an unanimous court) stated:

Section 6 of the [Social Assistance] Act properly construed, obliges the Director General to consider and decide upon an application for a social grant, and to do so lawfully, procedurally fairly, and with due diligence and promptitude. It goes without saying that a public functionary who fails to fulfil an obligation that is imposed upon him or her by law is open to proceedings for a mandamus compelling him or her to do so. That remedy lies against the functionary upon whom

58 Kate v MEC 2005 (1) SA 141 E 156 at par 21. Nicholson J in EN $v$ The Government of the Republic of South Africa Unreported Case No 4576/06 DCLD at par 30 expressed a similar view.

59 A discussion of the possible negative practical consequences of declaring s 3 of the State Liability Act unconstitutional are beyond the scope of this article. See $N v$ Government of Republic of South Africa (No 3) 2006 (6) SA 575 (D) 583 at par 29-30, 584 at par 32.

60 Ibid.

61 Ibid. 
the statute imposes the obligation, and not against the provincial government... Moreover, there ought to be no doubt that a public official who is ordered by a court to do or refrain from doing a particular act and fails to do so is liable to be committed for contempt in accordance with ordinary principles and there is nothing in Jayiya that suggests the contrary. ${ }^{62}$ (Own emphasis.)

\section{Delictual damages}

The plethora of cases in the Eastern Cape concerning social security grants have demonstrated a lack of accountability, a culture of passing the buck, complacency, incompetence and sheer laziness on the part of state officials in the employment of the Department of Welfare in the Eastern Cape. The only way to ensure compliance with court orders and legislation is to create individual and personal liability for state officials responsible for the implementation of not only court orders, but also the terms of legislation providing for social security. ${ }^{63}$

Ackerman J in Fose $v$ Minister of Safety and Security 1997 (3) SA 786 (CC) ${ }^{64}$ made the following remark:

The South African common law of delict is flexible and, under s 35(3) of the Interim Constitution, should be developed by the Courts with 'due regard to the spirit, purport and objects' of ch 3. In many cases, the common law will be broad enough to provide all the relief that would be 'appropriate' for breach of constitutional rights...

Nugent JA in MEC, Department of Welfare, Eastern Cape v Kate ${ }^{65}$ similarly expressed the view that the common law of delict 'is capable of being extended

62 MEC $v$ Kate 2006 (4) SA 478 (SCA) 492 at par 30.

63 As stated by Nugent J in MEC v Kate 2006 (4) SA 478 (SCA) 483 at par 27: “...the infusion of constitutional normative values into delictual principles itself plays a role in protecting constitutional rights, albeit indirectly. And no doubt delictual principles are capable of being extended to encompass state liability for the breach of constitutional obligations. But the relief that is permitted by $s 38$ of the Constitution is not a remedy of last resort, to be looked to only where there is no alternative - and indirect - means of asserting and vindicating constitutional rights."

64 Fose v Minister of Safety and Security 1997 (3) SA 786 (CC) 819 at par 58.

65 MEC $v$ Kate 2006 (4) SA 478 (SCA). 
to encompass state liability for the breach of constitutional obligations'. ${ }^{66}$ Since the state must act through its officials, we see no reason why a state official who negligently or in mala fides neglects to properly perform his duties (while acting on behalf of the state in his capacity as employee of the state), and so causes other(s) to suffer damages, cannot be held personally liable in delict for the damages so caused. ${ }^{67}$

As discussed under the previous heading, the Supreme Court of Appeal in Member of the Executive Council of Welfare $v K^{2} e^{68}$ unanimously held that a state official could be held liable for contempt of court. Given this fact, there is no reason why a state official should not be held civilly liable in delict for not complying with a court order or for simply not performing adequately in his capacity as state employee. Since the state has no choice but to act through its functionaries and officials, there is no better incentive to get the job done properly than the threat of personal civil liability for a dereliction of duties in their capacities as state employees. A further advantage of delictual liability is that the wronged person can be reimbursed for any loss or damage suffered.

Section 16 of the Social Assistance Act provides for the delegation of powers by the Executive Council and by the National Director-General of Welfare to the provincial Director-General and to officials in the employment of that department. If these powers have been so delegated and assigned to the various individuals, there is no need to second guess who should be held accountable in a delictual claim. As seen, the implementation of a court order by the state is dependent on the will to act and the competence of these state employees. ${ }^{69}$ Without individual accountability, there is no incentive, other than one's own sense of morality, which cannot always be guaranteed, to do one's job diligently. Where there has been contempt of court, delictual responsibility

66 Ibid at par 27.

67 In terms of s 239 of the Constitution an individual functionary is included in the definition of an organ of state. The Promotion of Administrative Justice Act 3 of 2000 (s1) has the same definition of "organ of state".

68 MEC v Kate 2006 (4) SA 478 (SCA) 491 at par 30.

69 See EN v Government of the Republic of South Africa (No1) 2006 (6) SA 543 (D) also reported as EN v Government of the Republic of South Africa 2007 (1) DCLR 84 (D). 
for failing to implement the court order can ultimately be assigned to certain functionaries as Froneman J did in Thozamile where the applicant sought, inter alia, an order to the effect that all administrative and other steps necessary to ensure that the provincial government complied with court orders. Froneman $\mathrm{J}$ stated:

The first respondent is the Premier of the province. The Constitution vests her with the ultimate executive authority of the province. The Premier and the Members of the Executive Council are responsible for the implementation of legislation in the province and for the performance of all other constitutional and statutory executive functions of the province. The Premier has taken an oath of office to 'obey, respect and uphold the Constitution and all other law of the Republic'.

This includes the duties to uphold the rule of law... As the ultimate executive authority in the province the Premier thus bears the ultimate responsibility to ensure that the provincial government honours and obeys all judgments of the courts against it.

The second respondent, the Member of the Executive Council for Finance, bears the same general Constitutional duties as those of the Premier, except that he does not bear the ultimate executive authority of the Premier. In addition, however, he bears the responsibility for decisions of the provincial treasury. This would include decisions relating to the payment of judgments against the province for the payment of money.

The third respondent, as a Member of the Executive Council for Social Development, in addition to being subject to the general constitutional duty of upholding, respecting and enhancing the rule of law, bears particular responsibility in that regard as the executive member of the department administering social grants.

So too does the fourth respondent. He is the accounting officer of the provincial department for social development. This means that amongst other duties, he is responsible for the payment of social grants, including those instances where the province is ordered to pay such grants by the courts.

Each of the four respondents thus bears the constitutional duty to act in accordance with the rule of law, which in the context of this application means that they must ensure that court orders made against the province are paid. That has not been done in a large number of individual cases referred to in this application. This failure, on the papers, is not the result of individual mistakes made by lower ranking officials. It is the result, on the one hand, of a fundamental misconception on the part of the province, represented by the 
respondents, about their duty to protect, uphold and enhance the rule of law. On the other hand it is the result of the lack of any systematic process of dealing with judgments for the payment of money granted by the courts against the province. The respondents represent the face of the province to the public. Between the four of them they are the state functionaries constitutionally and statutorily responsible for the payment of court orders made against the province in social grant matters. ${ }^{70}$ (Footnotes omitted; our emphasis.)

\begin{abstract}
A better solution would be for the court, once there has been a breach of duty on the part of the state, to name the persons responsible for fulfilling the terms of the order in terms of a structural interdict. If these terms are not abided by, then the named persons could be held liable for damages suffered on the basis of a delictual claim, provided of course that either negligence or mala fides on their part can be proved. ${ }^{71}$
\end{abstract}

The main advantages of a delictual claim are that the person who has suffered a loss is reimbursed for his or her loss and secondly it is an effective means of achieving accountability. To those who perceive personal delictual liability of state officials as a drastic measure, our response is two-fold. Firstly, drastic times call for drastic measures. When something as fundamental to the fabric of our society such as the rule of law is threatened and when the result of this is that the poorest sections of society are denied their constitutional rights to socio-economic rights and ultimately to life, it is clear that this state of affairs simply cannot be allowed to continue. Secondly, in the light of the fact that in order to succeed in a delictual claim both wrongfulness and damages have to be proved, there will be no liability unless the state official acted in an

70 Thozamile Eric Magidimisi v The Premier of the Eastern Cape Case Number 2180/04 at par 21-25. The court ia ordered: 1) That the Premier of the Eastern Cape's failure to cause the Eastern Cape Government to comply with prior orders constitutes an ongoing violation of their duties under the Constitution. 2) It declared that the Eastern Cape provincial government has a legal obligation and competence to satisfy the payment of court orders sounding in money made against the Provincial Revenue Fund. 3) The court set out time frames within which government must comply and report back to court of the manner and extent of their compliance. 4) Finally the court made provision for the Applicant to return to court and pursue contempt proceedings (and/or other competent relief) upon failure of the government (at par 39).

71 Obviously the state can also be held vicariously liable for its employees' wrongful acts. 
unreasonable manner. This is an objective test based on the convictions of the community. Therefore:

The basic question is whether, according to the legal convictions of the community and in the light of all the circumstances of the case, the defendant infringed the interests of the plaintiff in a reasonable or an unreasonable manner. ${ }^{72}$

Before a state official will be required to pay money out of his own pocket, he must have objectively conducted himself in an unreasonable manner. We do not think it is too much to ask of public officials that they act reasonably in the circumstances. Obviously, more can be expected of higher ranking officials. It does not seem unreasonable to expect those who occupy important positions in the employment of the state to be made accountable for their conduct in that capacity.

The second hurdle for delictual accountability, namely that the defendant acted wrongfully in causing the damages to the plaintiff, will ensure that innocent state officials who have done their duties in a reasonable manner do not have to pay damages. However, the disregard for human dignity and for the rule of law displayed by the officials of the Department of Social Welfare in the Eastern Cape is so outrageous that it will easily qualify as wrongful for the purposes of a delictual claim.

\section{Conclusion}

Personal accountability, be it civil or criminal on the part of state officials, is in our view an effective means of securing proper delivery of socio-economic rights to those in need. Without effective remedies for breaches by state officials the values underlying and the rights entrenched in the Constitution cannot be properly upheld or enhanced. Our common law of delict, combined with the provisions of the Constitution and the relevant sections in the Social 
Assistance Act can provide the accountability so essential for the delivery of socio-economic rights to those in such dire need of them. This is not to say however, that state accountability is excluded. Any breach of the Constitution by the state may be vindicated directly. ${ }^{73}$

The judiciary's innovative implementation of the structural interdict makes for an effective order in that time frames for fulfilment of the order can be set. Secondly, the courts can play a supervisory role in ensuring compliance with the order. If an order spells out the obligations of each named individual, and the order is not complied with, the hurdle of identifying who to sue in a delictual claim, or who to hold liable for contempt of court, will have been surpassed. Finally, in order to save time and costs the order can possibly state, as was suggested in Thozamile, ${ }^{74}$ that should the order not be complied with, the applicants can at a later stage proceed on the same papers.

The structural interdict need not take the form of a money order, but can nevertheless achieve the same result. For example, the order can provide that a state official or several named state officials must see to it that systems are put in place in order to ensure that the applicants' social grants are promptly paid out. Since this is not a money order, it circumvents the rule that a state official cannot be liable for contempt of court when a money order is not adhered to. In this way the state officials, in addition to being held liable in delict, can also be found criminally liable and imprisoned for contempt of court should they fail to abide by the terms of the structural interdict. In a delictual claim, the applicant must prove wrongfulness. Similarly, in a case for contempt of court, the defendant who furnishes good reasons for not adhering to the court order will be exempt.

We believe that personal accountability of lazy and incompetent state officials is an effective way of ensuring that the rule of law is upheld and that socio-

73 N 65.

74 Thozamile Eric Magidimisi v The Premier of the Eastern Cape Case Number 2180/04 par 21-25 at par 39. 
economic rights are delivered to the poorest of the poor. Personal accountability will encourage state officials to perform up to standard thus discouraging litigation and the consequent unnecessary financial burden on the state. $^{75}$

We are certainly not faced with insurmountable difficulties. The courts have already in a very innovative fashion created remedies not only to assist the poor in effectively executing their orders but also in restoring equality before the law. ${ }^{76}$

75 In Vumazonke $v$ MEC 2005 (6) SA 229 (SE) 234 at par 5 Plasket J provided the following estimates: "I have obtained from the Registrar a copy of a bill taxed in a similar matter... On that basis these matters tax out at about R 4000 per case. It would mean therefore that in today's cases alone about 100000 will be paid out in legal costs in respect of the fees and disbursements of the legal representatives of the applicants. Clearly millions of rand in taxpayers' money have been wasted in unnecessary legal costs occasioned by indolence and/or incompetence on the part of public servants."

76 There always is the possibility of structural remedies against the National Social Development Department and/or Social Security Agency to ensure that proper systems are put in place. However, we feel that the personal liability of state officials would be more effective means of ensuring compliance. 


\section{Bibliography}

Davies 200622 SAJHR 301

Davies DM "Adjudicating the Socio-Economic Rights in the South African Constitution: Towards 'Deference Lite'?” 200622 SAJHR 301

Neethling, Potgieter and Visser Law of Delict Neethling J, Potgieter JM and Visser PJ Law of Delict $5^{\text {th }}$ ed (LexisNexis Butterworths Durban 2006)

Pillay 2002 Economic and Social Rights Review 11

Pillay K "Implementing Grootboom: Supervision Needed" 20023 Economic and Social Rights Review 11

Swart 2005 SAJHR 215

Swart M "Left out in the Cold? Crafting Constitutional Remedies for the poorest of the Poor" 2005 SAJHR 215

Trengrove 1999 Economic and Social Rights Law Review 8-10

Trengrove W "Judicial Remedies for Violations of Socio Economic Rights" 19991 (4) Economic and Social Rights Law Review 8-10

\section{Register of cases}

City of Johannesburg v Rand Properties 2006 (6) Case No 253/06 (SCA) East London Transitional Local Council v Member of the Executive Council of the Province of the Eastern Cape for Health and Others 20004 All SA 443 (CK)

EN and Others $v$ The Government of the Republic of South Africa and Others Unreported Case No 4576/06 DCLD

EN and Others v Government of the Republic of South Africa 2007 (1) DCLR 84 (D)

Fose $v$ Minister of Safety and Security 19973 SA 786 (CC)

Government of the Republic of South Africa and Others $v$ Grootboom and Others 200011 BCLR 1169 (CC) 
Government of the Republic of South Africa v Grootboom 20011 SA 46 (CC) Jayiya $v$ Member of the Executive Council for Welfare, Eastern Cape and another 2004 (2) SA 611 (SCA)

Kate $v$ The Member of the Executive Council for the Department of Welfare 2005 (1) SA 141 (SE)

Kiliko and Others $v$ Minister of Home Affairs and Others 2006 (4) SA 114 (C) MEC, Department of Welfare, Eastern Cape v Kate 2006 (4) SA 478 (SCA) Minister of Health and Others v Treatment Action Campaign and Others 20025 SA 721 (CC)

Mjeni v Minister of Health and Welfare, Eastern Cape 20004 SA 446 (Tk) $N$ and Others $v$ Government of Republic of South Africa and Others (No 3) 2006 (6) SA 575 (D) $N$ and Others $v$ Government of the Republic of South Africa (No 1) 2006 (6) SA $543(\mathrm{D})$

Ngxuza v Permanent Secretary, Department of Welfare, Eastern Cape Provincial Government 20012 SA 609 (E)

Permanent Secretary, Department of Welfare, Eastern Cape Provincial Government v Ngxuza 20014 SA 1184 (SCA)

President of the Republic of South Africa and Others $v$ Modderklip Boerdery Pty Ltd (Agri SA and Agri SA and Legal Resources Centre, Amici Curiae) 2004 6 SA 40 (SCA)

Rail Commuters Action Group and Others v Transnet Ltd t/a Metrorail and Others 2005 (2) SA 359 (CC)

$S$ v Mfezeko Zuba and 23 similar Cases 20044 BCLR 410 (E) Soobramoney v Minister of Health, Kwazulu Natal 19981 SA 765 (CC) Thozamile Eric Magidimisi NO $v$ The Premier of the Eastern Cape, The MEC For Finance Eastern Cape, The MEC for Social Development Eastern Cape, The Head of the Department of Social Development Eastern Cape, The Mister of Justice Case Number 2180/04 marked Reportable Vumazonke v MEC for Social Development Eastern, Cape and Three Similar Cases 20056 SA 229 (SE) 


\section{Register of legislation}

Abolition of Civil Imprisonment Act 2 of 1997

Constitution of the Republic of South Africa 1996

Immigration Act 13 of 2002

Promotion of Administrative Justice Act 3 of 2000

Social Assistance Act 13 of 2004

State Liability Act 20 of 1957

Welfare Laws Amendment Act 106 of 1997

\section{Register of internet sources}

Broughton The Mercury http://www.iol.co.za/ 29 Dec

Broughton T "Annoyed judge questions social grant cases" The Mercury 30 July 2007 [Found on internet]

http://www.iol.co.za/general/news/newsprint.php?art id=vn2007073004255 4688C323016\&sf= [Date of use 29 December 2007]

\section{List of abbreviations}

$\begin{array}{ll}\text { ch } & \text { chapter(s) } \\ \text { eg } & \text { for example } \\ \text { ia } & \text { inter alia } \\ \text { par } & \text { paragraph(s) } \\ \text { s } & \text { section(s) } \\ \text { TAC } & \text { Treatment Action Campaign }\end{array}$

